\title{
Ethnoornithological study in selected villages of Riau Province, Indonesia
}

\author{
ELFIS", PRIMA WAHYU TITISARI, NUNUT SUHARNI, KHAIRANI, NADIATUL JANNA, \\ TIKA PERMATASARI, INDRY CHAHYANA \\ Department of Biology, Faculty of Education, Universitas Islam Riau. Jl. Kaharuddin Nasution No. 113, Marpoyan, Pekanbaru 24284, Riau, Indonesia \\ Tel./fax.: +62-761-674834.`email: elfis@gmail.com; pw.titisari@uir.ac.id
}

Manuscript received: 21 October 2019. Revision accepted: 26 March 2020.

\begin{abstract}
Elfis, Titisari PW, Suharni N, Khairani, Janna N, Permatasari T, Chahyana I. 2020. Ethnoornithological study in selected villages of Riau Province, Indonesia. Biodiversitas 21: 1645-1652. Riau Province, along the central-eastern coast of Sumatra, is an area of high bird diversity. The purpose of this study is to document and analyze the ethnoornithological local wisdom of some selected villages and use it to develop a strategy for biodiversity conservation in Riau. The method used in this research involved direct observation of some areas that have local accumulated natural history knowledge and interviews with selected informants of the local community. Some bird species were found to be central to the local culture, and these included the Punai Saluang/Sumatran Greenpigeon (Treron oxyura Temminck), Serindit Melayu/Blue-crowned Hanging Parrot (Loriculus galgulus Linnaeus), Bubut/Greater Coucal (Centropus Sinensis Stephens), and Rangkong Gading/Helmeted Hornbill (Rhinoplax vigil Forster). These bird species are used in traditional medicine, rituals and symbols in Riau Province. Serindit Melayu/Blue-crowned Hanging Parrot is a symbol of the Malay community in Riau and averts evil in the village of Gema. Rangkong Gading/Helmeted Hornbill body parts are used in ritual treatment to cure various diseases by the TalangMamak Tribe in Rantau Langsat. Punai Saluang/Sumatran Green-pigeon is used as a metaphor in folk literature of the Malays in the Pelalawan area, and Bubut/Greater Coucal (Centropus sinensis Stephens) body parts are used as traditional medicine by the Malays in Kuok Village. There are several aspects that need to be studied further to conserve these birds, including the ecology, reproduction, and behavior aspects. Through preservation of these ethnoornithological rituals and education of the younger generation, these and other species of birds can be better sustained in and around the culture of Riau society.
\end{abstract}

Keywords: Centropus sinensis, ethnoornithology, Loriculus galgulus, Rhinoplax vigil, Treron oxyura

\section{INTRODUCTION}

Indonesia has the fourth-highest richness of bird species in the world (Sukmantoro et al. 2007). Only Colombia, Peru and Brazil host more species than Indonesia. The country of Indonesia is estimated to have 1777 species of birds, which is $17 \%$ of the total bird species diversity in the world. Of these species, 168 are considered as threatened which includes 30 critically endangered species, 44 endangered species and 94 vulnerable species (IUCN 2018). However, only about 557 species have been protected by the Government Regulation of the Minister of Environment and Forestry P.106 of 2018. The increased threat of extinction is caused by intensive illegal hunting of birds which is still rife with an increasing trend from year to the year, especially for singing birds, loss of habitat due to land-use change, and the use of pesticides (Mudappa and Raman 2009; Gonzales 2011; Trisurat et al. 2013; Naniwadekar and Datta 2013; Iskandar et. al. 2016; Titisari et al. 2016; Aik and Perumal 2017; Franco and Minggu 2019).

Indonesia is not only high in biodiversity, but it is also one of the largest multicultural countries in the world, with large number of ethnic, cultural, religious, and other groups. Each community has local wisdom, traditional wisdom, local knowledge (local expertise) or local intelligence (local genius) and indigenous knowledge that has accumulated in their traditions, songs, and legends. The resilience of the local culture is greatly influenced by the efforts to preserve the traditions of the community. Local wisdom can be realized in various aspects of life, both directly and indirectly. Local wisdom is a system in the social, political, cultural, economic and environmental life structure that is manifested in the form of a set of rules, knowledge, skills, values, and ethics that govern the social order of a community and continues to live and develop from generation to generation (Semiawan 2004; Alim 2018; Edorita et al. 2018).

Riau Province has an especially high level of biodiversity that includes many endemic species of plants and animals. Several studies of birds in locations within Riau Province, such as Tesso Nilo (WWF 2004), PT. Riau Sawitindo Abadi, Indragiri Hilir District (Arief et al. 2015), Rumbio customary forest, Kampar District (Sabaruddin et al. 2017), and Rengat, Indragiri Hulu District (Syaputra et al. 2017) have been conducted.. In addition, Riau Province also has a complex cultural system. Riau Malay society is full of cultural values useful for conserving the environment. The wisdom of maintaining environmental sustainability can be seen in their socio-economic system, for example in maintaining customary forest lands, fishing, gathering honey, river maintenance, maintaining water and terrestrial ecosystems. Utilization of many species, including birds, is closely related to local knowledge of 
each community. However, if the existence of bird species is increasingly threatened, it will affect the sustainability of traditional cultural practices of Malay communities in Riau.

Traditional cultural practices are intertwined with sustainable use of biological resources and environmental preservation because culture has been shaped by local ecosystems, including biotic and abiotic elements. Traditional knowledge systems and practices can be used to anticipate, recognize and respond to change. When indigenous peoples and local communities respond to the effects of modernization, land-use change and climate change, a wealth of ecological knowledge and practices is needed to help individuals adapt and survive. Some of the most relevant cultural features, such as religious beliefs and practices, have long influenced human perception and use of biological resources. Cultural diversity and spiritual needs have long been linked to the way humans use and interact with biodiversity, and in some parts of the world, the belief in the sacred nature supports human relations with biological resources either through creation myths or various other beliefs and practices. Recent studies exploit cultural and spiritual values in the context of biodiversity conservation, but their role in biological conservation and ecosystem resilience is still largely ignored. The preservation of birds can be maintained by conserving species that were preceded by various studies or research on these animals including ethnoornithology studies (Alves et al. 2012).

Ethnoornithology can be understood as the relationship between birds and ethnicity (community groups) in various parts of the earth, and society in general. Ethno-ornithology is used as a tool to document the knowledge of traditional communities, which have used various types of bird services to support their lives, for example, as a source of food, traditional medicine, traditional rituals, crafts, religion, and social life (Silviyanti et al. 2016). Birds have been used by humans for thousands of years for various purposes, such as traditional use as food, the exploitation of certain body parts as jewelry and decorative accessories, to traditional medicine (Alves et al. 2012; Sodhi et al. 2011; Gonzales 2011). The objective of this study is to document the uses of birds by some Riau Malay local communities in selected villages of Riau Province, Indonesia.

\section{MATERIALS AND METHODS}

\section{Study area}

The research was conducted in Riau Province, Indonesia, includes Kuok and Gema villages of Kampar District; Talang Durian Cacar and Rantau Langsat villages of Indragiri Hulu District, and Betung and Kesuma villages of Pelalawan District (Figure 1). The study will be conducted from March to October 2019. Research Locations in Kuok and Gema Villages in Kampar District. Talang Durian Cacar and Rantau Langsat villages in Indragiri Hulu District and Betung and Kesuma Villages in Pelalawan District. These six villages can representatively be used to describe the use of birds in the traditional treatment process. The villages of Talang Durian Cacar and Rantau Langsat use traditional medicine from the Talang Mamak tribe led by a dukun called Balian. Betung and Kesuma villages use traditional Petalangan Malay medicine led by a shaman called Bathin. The villages of Kuok and Gema use traditional Malay Kampar medicine, led by a dukun called Dukun Tuo.

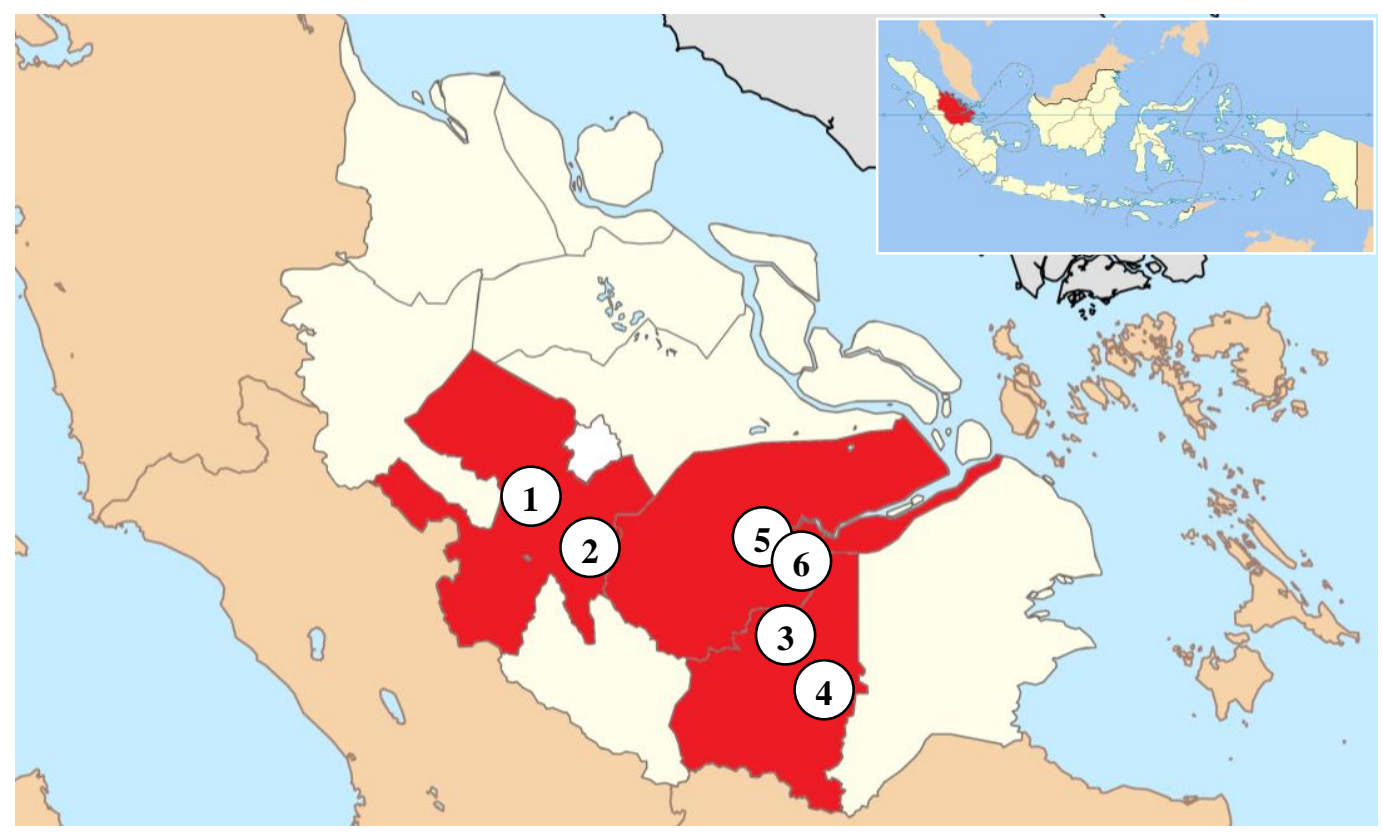

Figure 1. Research locations in Riau Province, Indonesia. 1. Kuok Village, Kampar District, 2. Gema Village, Kampar District, 3. Talang Durian Cacar Village, Indragiri Hulu District, 4. Rantau Langsat Village, Indragiri Hulu District, 5. Betung Village, Pelalawan District, 6. Kesuma Village, Pelalawan District 
Table 1. Functions and benefits of birds

\begin{tabular}{ll}
\hline Species & Functions and benefits \\
\hline Punai Saluang/Sumatran Green- & Used as a metaphor in \\
pigeon(Treron oxyura Temminck) & poetry and legends \\
Bubut/Greater Coucal (Centropus & Used in traditional \\
Sinensis Stephens) & medicine \\
Serindit Melayu/Blue-crowned & Used as a Riau mascot \\
Hanging Parrot (Loriculus & and in literature and \\
galgulus Linnaeus) & traditional rituals \\
Rangkong Gading/Helmeted & Used in ritual treatment \\
Hornbill(Rhinoplax vigil Forster) & \\
\hline
\end{tabular}

\section{Procedure}

The method used in this study was qualitative with ethnoornithological descriptive analysis or ethnobiological approaches (Ellen 1993a; Ellen 1993b; Diamond 1999; Newing et al. 2011; Iskandar 2012; Albuquerque et al. 2014). Field data collection techniques included direct observation, participant observation, and d semi-structural or in-depth interviews. The authors conducted in-depth interviews with 33 informants chosen deliberately by the snowball technique (Newing et al. 2011; Albuquerque et al. 2014). The informants chosen included 10 elderly people, 5 formal and informal village leaders, 8 traditional healers, and 10 bird hunters belonging to the study villages. Before conducting in-depth interviews with informants, the nature and purpose of the study were explained, and permission for the interviewees was obtained to record their information (Alves et al. 2013).

The interview guide contains the local language names of birds, their morphological characteristics, special sounds, special colors, habitat types, roles in ecosystems and socio-culture, and details of hunting. To identify and validate bird species during interview, researchers showed images of birds present in field guide books for birds in Sumatra, Western Indonesia, and Southeast Asia (King et al. 1975, MacKinnon et al. 1992). In addition, participant observation was also conducted by researchers during fieldwork (Newing et al. 2011). For example, researchers accompanied bird hunters into the forest.

\section{RESULTS AND DISCUSSION}

The Malay people of Riau use some birds commonly in their daily life, as metaphors, medicines, and also as a symbol of Riau. Malay society has a high dependence on the existence of several species of birds because Malay society is a society that still values the wisdom and culture of living things. A list of birds with their different functions or uses Is given in table 1.

In Figure 2 about the functions and advantages of utilizing birds in ritual activities, it can be explained as follows: (A) Rangkong Gading/Helmeted hornbill (Rhinoplax virgil Forster) in Talang Mamak Tribe used in
Bulean ritual which is a type of treatment ceremony as a solution in treating illness by using inner strength to get closer to supernatural beings, for healing the sick. The Talang Mamak community believes that a disease suffered by a person is caused by the emptiness of the soul for a moment, so that his body is entered by a supernatural being or a certain force that causes humans to get the disease. The disease can be cured by the handler or kemantan, by calling the human soul to return to his body. The treatment process besides using medicinal ingredients consisting of various leaves and various wood veins, handler or kemantan also uses motion as one of the media used to expel evil spirits from the human soul which is presented in the form of Bulean ritual. The traditional ritual is led by a Pawang or Kemantan assisted by a Pebayu and Bujang Belian. In the ritual the drum (ketobang) has an important role to accompany the magical dance and recitation of a chant sung by the handler in an unconscious state. The ritual consists of several stages, namely: seeing the disease, looking for drugs, making drugs, using drugs and closing drugs (memoti). Pawang or Kemantan uses a mask from the head of a Rangkong Gading/Helmeted hornbill (Rhinoplax virgil Forster) and mimics the movement of a Helmeted hornbill while reading a medical spell.

Furthermore, in (B) Bubut/Greater Coucal (Centropus Sinensis Stephens) play a role in ritual treatment in Kuok Village, Kuok Sub-district, Kampar District, especially in the treatment of broken bones, lathes can heal or help the healing process of broken bones faster, because bird has calcium content is very much so that it can make bone cells can regenerate quickly. In the treatment of processed flu, the food from lathe is bird soup, with a savory and tender meat taste combined with various types of spices such as ginger, and ginseng. To treat asthma, patients generally drink bird oil directly or by mixing it in food. For sufferers who have burns whether mild to severe, can apply bird oil to speed up the healing process and eliminate burn scars. This has proven to be quite effective, because lathe oil can stimulate skin cell regeneration faster. Furthermore, in (C) Serindit Melayu/blue-crowned Hanging Parrot (Loriculus galgulus Linnaeus) has been known in various folklore and is a symbol of wisdom, wisdom, beauty, courage, loyalty, humility, Riau Malay society. In the story of the Riau Malay community, this bird is called the title Panglima Hijau. In the life of the Riau Malay community, the caged birdcage is hung in front of the house, with a position not far from the front door, this placement is associated with the belief that serindit can resist reinforcements, such as magic, epilepsy and so on. The variety of symbols and myths possessed by these serindit birds causes the elements of this bird to be incorporated into the symbol of Riau Province, namely in the Hulu Keris called Hulu Keris Kepala Serindit, which symbolizes courage, wisdom, and wisdom in upholding the truth and justice. The Keris symbol is used by the people of Melayu Riau as a symbol of pride, which is used as a symbol of the complete traditional clothing section of Riau, its Serindit motif. 


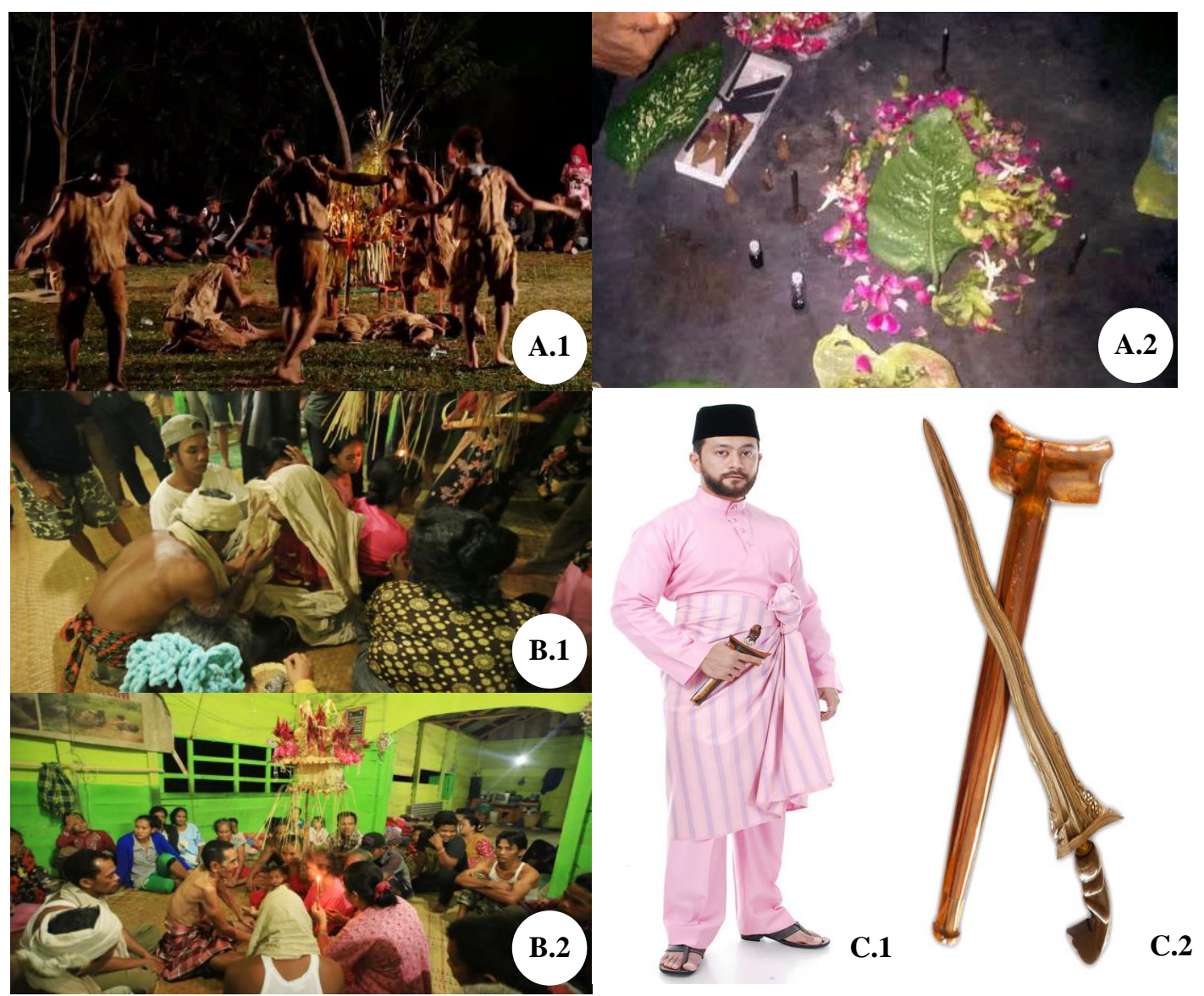

Figure 2. Traditional rituals and treatment methods connected with birds: A. Bubut/Greater Coucal (Centropus Sinensis Stephens), B. Rangkong Gading/Helmeted hornbill (Rhinoplax vigil Forster), C. Serindit Melayu/Blue-crowned hanging parrot (Loriculus galgulus Linnaeus)

\section{Punai Saluang/Sumatran Green-pigeon (Treron oxyura Temminck)}

Pelalawan is where the Punai Saluang /Sumatran Green-pigeon (Treron oxyura Temminck) (Figure 3.A) occurs in Riau. Punai Saluang still has a large population. In Pelalawan District, there are $\pm 10,000$ birds of Punai Saluang. The male Punai Saluang has a dark green top with a blue-gray necklace. The lower body is green with a yellowish belly and chest. The main wings are blackish in color and have long tails and a gray taper. In the female Punai Saluang, the abdomen does not have a yellow color. It has a bluish-green iris, a blue-green beak, red legs, and green undercoat covers. Punai Saluang is an endemic bird of Java and Sumatra. On the island of Java, this bird can only be found in the area of West Java, around the area of Mount Papandayan. While in Sumatra, this bird can be found in the Bukit Barisan area. Punai Salung Habitat is tropical and subtropical forest in the lowlands. They live in a nomadic group, but never far from a dense hill forest with a height of about 350 to $3000 \mathrm{~m}$ above sea level. According to David et al. (2015), this bird also helps in seed dispersal.

Appropriate forest habitat can support large populations of this pigeon in Indonesia. However, there are two other species of pigeons called punai in Pelalawan District, namely Punai Tanah/Gray-capped emerald dove
(Chalcophaps indica Linneaus) and Punai Saluang/ Sumatra Green-pigeon (Treron oxyura Temminck). Punai Saluang has a higher number compared to Gray-capped emerald dove (Chalcophaps indica Linneaus). Punai Saluang, which is often sold and kept in captivity, is eaten by the Pelalawan people. This is due to the larger population of Punai Salung. The selling price of Punai

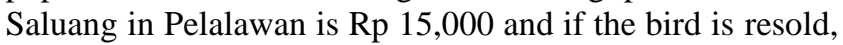
the selling price reaches Rp 50,000. Birds that are sold are judged by the beauty of their feathers, the more beautiful the feathers of the bird, the selling price is higher. The proceeds from the sale of Punai birds can add to the community's economy. This bird is sold as a pet or to be consumed.

Punai, in the Malay community Pelalawan, is used as a metaphor in rhymes and legends. There is a saying that is quite popular "Expect high-flying birds to be absent from the hands that released them". This has profound meaning because you hope for something greater if you let go of something valuable that was secure in your hand. In addition, there are also rhymes that remind us to make the best use of time. This poem also has a spiritual meaning, that our lives will not be eternal in this world. A young person should be aware that one day he will leave his youth 
and worldly life, so he is expected to always use his youth to worship God and fill his days with useful deeds.

burung punai terbang ke utara (pigeons fly to the north) pada sekawanan hendak mencari (with their group want to search)

jangan sia-siakan masa muda (don't waste your youth)

karena ia takkan kembali (because it won't come back)

In addition to figures of speech and rhymes, birds are also found in the Story of the Bujang Perajuk (Oral Literature of Pelalawan Malay). The Riau Malay community, especially in Pelalawan, believes that the origin of the birds was from Si Bujang, who was getting more and more naughty and rarely returned home, so his attitude made his parents' hearts sad and did not care about their son, Si Bujang. In this story, before the Bujang turned into a Bird of Punai, he sang a song as follows:

sing... tali gasing (spinning top... spinning top)

alit gasing dan buah keras (small spinning top and harsh fruit)

sampai hati ibu! (how could you, mother!)

ditanaknya saya gasing (she cooks me a spinning top)

digulainya tali gasing (she cooks rope of sipinning top)

menjadi punai-punai jugalah saya hendaknya (so I

become a pigeon)

makan buah kayu ara (and eat the fig fruit)

There are two moral values that can be drawn from the story of this pigeon, namely the importance of educating children and the consequences of being a lawless child. For Malays, educating and defending children is very important. The goal is that their children will be "menjadi orang", which is to become a perfect physical and inward human being. Parents hope that their child will be "anak bertuah", which can bring happiness, spaciousness, harmony, and well-being for the family and for the community. Malay elders say "kalau anak menjadi orang, kecil menjadi tuah rumah, besar menjadi tuah negeri". Ungkapan lain mengatakan, "tuahnya selilit kepala mujurnya selilit pinggang, ke tengah menjadi manusia ke tepi menjadi orang." The child who has been "menjadi manusia" or "menjadi orang" also called "anak bertuah", because they can bring happiness, pride, and luck to their families, communities and nations.

\section{Bubut/Greater Coucal (Centropus sinensis Stephens)}

Bubut/Greater Coucal (Centropus sinensis Stephens) (Figure 3.B) is one of the birds used in traditional knowledge by local communities in Kuok Village, Kuok Sub-district, Kampar District. Several groups use the Bubut/Greater Coucal as traditional treatment, as conveyed by Datuak Dalang (traditional healer in Kuok Kampar). Body parts such as the Bubutoil, has benefits in treating broken bones, colds, asthma, and burns. Treatment using lathes was apparently also carried out abroad, such as in Vietnam and India, where Bubut/Greater Coucal was used as traditional zootherapeutic and mixed into alcohol (Van and Tap 2008; Mahawar and Jaroli 2008; Rozzi 2010). The local wisdom of the Kuok Village community in using traditional medicine using lathe is a hereditary knowledge in each generation.

Treatment using lathe is not only as an external medicine, but also consumed with certain preparations. Given below are the treatments carried out using Bubut/Greater Coucal: (i) Bubut/Greater Coucal soup prepared from tender meat combined with various types of spices such as ginger, galangal is used to treat flu (ii) Bubut/Greater Coucal is processed into lathe oil which is consumed directly or by mixing in food, to treat asthma (iii) Oil and Bubut/Greater Coucal soup contains calcium which can make bone cells can regenerate quickly. Therefore, its used to heal broken bones (iv) Applying Bubut/Greater Coucal oil accelerates the burn healing process and eliminates burn scars.

The method of making and using lathe oil is as follows: (i) Bubut/Greater Coucal nest leaves soaked in green coconut oil containing Bubut/Greater Coucal that has been slaughtered halal, (ii) this oil is used to massage broken legs. The sound of Bubut/Greater Coucal was considered as an indication of sad news in the area of Ketapang District, West Kalimantan (Silviyanti et al. 2016). This bird's nest Bubut Alang-alang is also used as a pain reliever for crying babies.

\section{Serindit Melayu/blue-crowned Hanging Parrot (Loriculus galgulus Linnaeus)}

Serindit Melayu/blue-crowned Hanging Parrot (Loriculus galgulus Linnaeus) (Figure 3.D), is spread in lowland forest to an average height of $1,300 \mathrm{~m}$ above sea level. This bird population occurs in Brunei, Indonesia, Malaysia, Singapore, and Thailand. Serindit Melayu is a typical pet of the Riau province together with Nibung (Oncosperma tigillarium) which is considered important in the flora of the Riau province's identity. In the myth, this Malay serindit bird is inserted into the symbol of Riau Province, namely the "Hulu Keris" called "Hulu Keris Kepala Serindit", which symbolizes courage and wisdom in upholding truth and justice. The keris is a part of the complete traditional clothing of Riau, which on the upstream of the keris is Serindit. In Riau folklore, especially in the story of the faunal world, this bird is called the "Panglima Hijau".

Serindit Melayu is included in the old Malay literary treasures, Syair Ken Tambuhan (SKT) and Hikayat Andaken Penurat (HAP). In Syair Ken Tambuhan, it is said that a serindit bird flies after being choked by the war lord (Raden Inu/Andaken Penurat), the bird flew and perched on a shady cempaka (Magnolia champaca) tree inside the prohibited park, where Ken Tambuhan was weaving. The warlord (Raden Inu/ Andaken Penurat) was then forced to rescind the ban on the park door, and the moment the door was opened he also looked at the face of Ken Tambuhan and fell in love with her. From the Malay literary treasures, Serindit Melayu is considered a love bird, because it signifies the presence of love in its main characters.

The Serindit Melayu is also included in the rhymes, such as rhymes from Rokan Hulu as follows:

burong selindit ateh paga (hanging parrot on the fence) 
jatuh budibum ke dalam padi (fell into a pile of rice) siki sukocik munyadi sosa (although it is a small thing, still regrettable)

indo di muluik di dalam hati (if it is not expressed in words, at least in the heart)

Apart from the poem, Serindit Melayu is also used in the poetry which becomes the lyrics of a Malay song Awallah Dondang:

serindit putih di dahan manggis (White hanging parrot in Mangosteen's limb)

kemana pergi burung kenari (where canaries go)

langit merintih awan menangis (the sky whimpered and the clouds cried)

lukanya hati tanggung sendiri (a broken heart must be healed by yourself)

In addition to being a literary inspiration in the form of narrations and rhymes, Serindit Melayu is also used as inspiration for the Sultan Syarif Kasim II Airport, adapting the name to one of the meeting rooms in the Regional Building (Balai Serindit), the name of the Malay keris hulu motif (Kepala Serindit), and the PON XVIII/2012 mascot (Bujang Serindit) (Figure 3.E). Besides being maintained for its beauty, some Riau Malay people use this bird in ritual activities. For example, in the village of Gema, Serindit Melayu used as a magic repellent and to treat epilepsy of children. If maintained along with chickens, it will be believed to accelerate the breeding of chickens. It is usually kept hanging in front of the doorway of the house. For the people of Siak District, Riau, it is a motif which is a symbol of Malayan wisdom (Lestari and Riyanti 2017). Little is known about reproductive behavior of this bird in captivity and even less in the wild. However, according to Buckley (1968), this bird holds food either in the legs or beak, pseudo-sleeps upside down in response to the appearance of potential predators, and nest making is by both male and female.
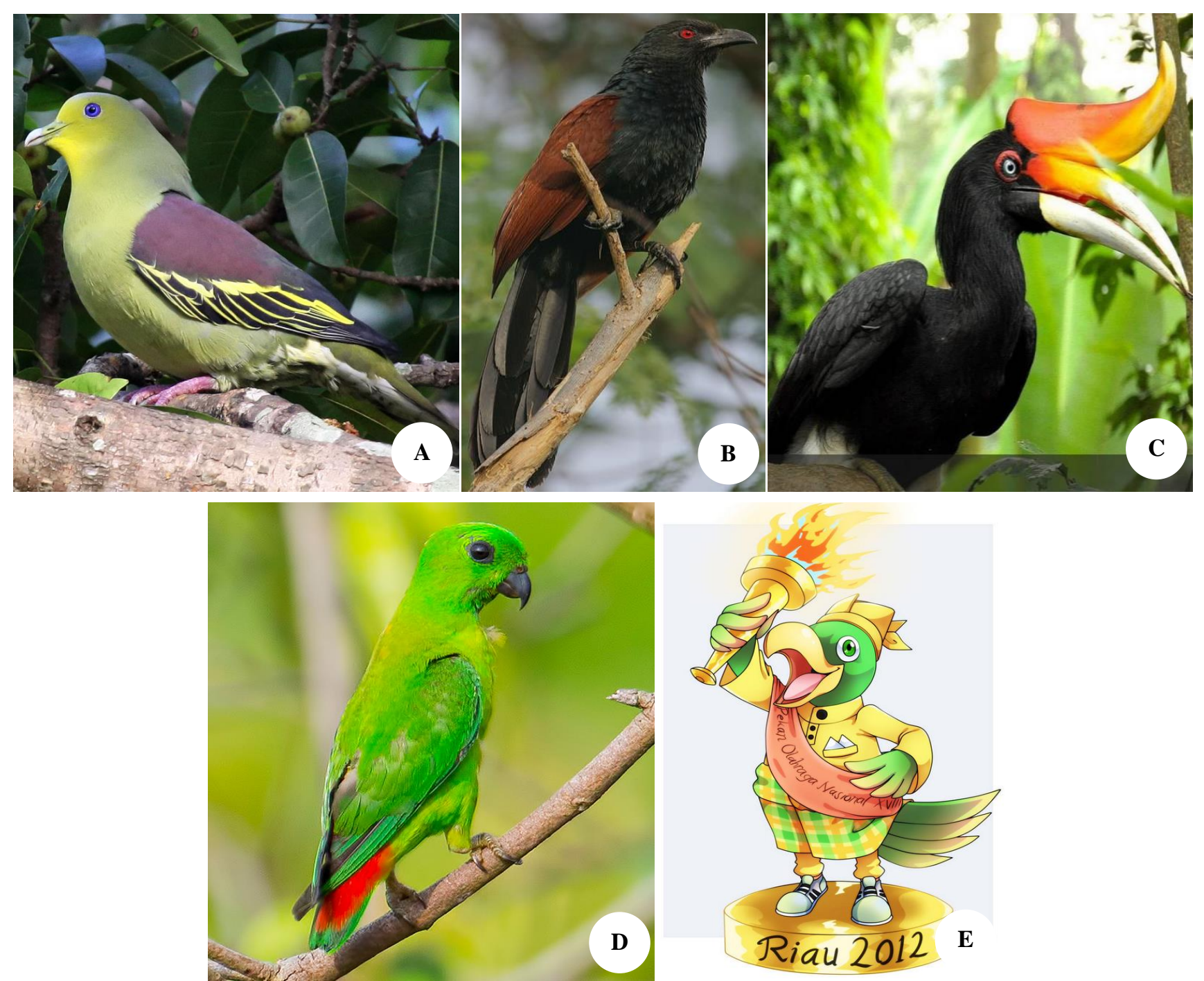

Figure 3.A. Punai Saluang/Sumatran Green-pigeon (Treron oxyura Temminck), B. Bubut/Greater Coucal (Centropus sinensis Stephens) C. Rangkong Gading/Helmeted hornbill (Rhinoplax vigil Forster), D. Serindit Melayu/blue-crowned Hanging Parrot (Loriculus galgulus Linnaeus), E. Mascot PON XVIII/2012 "Bujang Serindit" 
Though not a protected bird in Indonesia, Serindit Melayu/Blue-crowned hanging parrot (Loriculus galgulus Linnaeus) is listed in the IUCN Red List with the conservation status of Least Concern. CITES registered it in Appendix II, which means that its trade must go through strict supervision.

\section{Rangkong Gading/Helmeted hornbill (Rhinoplax vigil Forster)}

Hornbills (Rhinoplax vigil Forster) (Figure 3.C) are known to play an important role as agents of seed dispersal (Franco and Minggu 2019). The Sumatra region, especially Riau Province, is home to several species of hornbills, one of which is the Rangkong Gading/Helmeted Hornbill (Rhinoplax vigil Forster). This bird is found in several forest areas of Riau. Some community groups in Riau, like the Talang Mamak tribe, utilize the hornbill as a part of a ritual treatment called "Onggang Godiang", which is performed to cure diseases, as explained below.

Talang Mamak tribe people who formerly adhered to animism strongly believe in the majesty of its spirit, and that it can provide health, safety, and peace. The adat ritual of the Talang Mamak Tribe considers the Rangkong Gading as an incarnation of a god and is always cherished, in a ritual called the Bulian which is performed once a year in propitious months by the shaman/dukun /batin of the tribe. After the shamans from a number of clans determine a day to carry out the traditional ritual, they start looking for hornbills. Only the shamans are entitled to search and hunt the birds. After the shaman captures a Rangkong Gading, the bird is sacrificed and the bird's head is used as a transcendental medium (connecting to other worlds) to summon the deities or spirits they consider. After that, the beak of the bird is immersed in water and the beak is purified, then the purifying water of the Rangkong Gading beak is given to the affected community members so that they can recover. During the ceremony, they also perform offering dances that mimic the movement of hornbills, known as the "Rentak Bulian" dance.

Besides being used in traditional rituals by the Talang Mamak tribe (Silviyanti et al. 2016), the sound of Hornbill Ivory is also used as an indicator of rain in the Ketapang District, West Kalimantan. Rangkong Gading is also included in the cultural values of West Kalimantan and Philippine islands (Gonzales 2011) in the form of folklore and poem. However, the Talang Mamak people now rarely use Rangkong Gading as medicine, because these birds are so difficult to find. This is due to the poaching done so far to obtain the beaks of these birds for sale, even though all hornbill species in Indonesia are protected animals. Data from Eaton et al. (2015) and Beastall et al. (2016) indicates that, besides Indonesia, this bird is also traded up to China and Myanmar.

Human activities pose an important threat to the existence of birds. About $95 \%$ of threatened birds around the world experience habitat loss, around $70 \%$ of which are related to human activities resulting in a decline in species populations. As discussed by Franco and Minggu (2019), there was a decline in the Helmed Hornbill population in
Brunei Darussalam and also in several other countries; Philippines (Gonzales 2011), Thailand (Trisurat et al. 2013), India (Naniwadekar and Datta 2013; Mudappa and Raman 2009), and Malaysia (Aik and Perumal 2017). Great pressure on bird populations by humans shows that conservation measures must involve interactions between local communities and birds in the region. Therefore ethnoornithological studies are needed because they provide basic information for designing conservation strategies and promoting public policies that are expected to reduce the rate of overexploitation of bird population. Some efforts are needed to protect the existence of birds so that cultural sustainability in the community is maintained according to IUCN (2018), including eliminating all bird trade activities by strengthening regulations, protecting bird populations by preserving their natural habitat, and gathering all forms of information related to exploitation, trade and the existence of birds from various sources. Conservation must also consider cultural, economic, and social aspects.

\section{ACKNOWLEDGMENTS}

Authors would like to thank all the key respondents and community leaders of all study villages who have participated in and contributed to this study, and all others who have helped so that this research is successfully completed.

\section{REFERENCES}

Aik YC, Perumal B. 2017. Distribution of Hornbills and Important Hornbill Landscapes Setting Site Conservation Priorities for Peninsular Malaysia. Paper Presented in the 7th International Hornbill Conference.

Albuquerque UP, da Cunha LVFC, de Lucena RFP. 2014. Methods and Techniques in Ethnobiology. Springer, New York.

Alim N, Syamsuddin. 2018. The Establishment of Multicultural-Based Team Characteristics in Increasing Institution Productivity of Higher Education in Indonesia. IOP Conf Ser: Earth Environ Sci 175 (1): 012146.

Alves RRN, Leite RCL, Souto WMS, et al. 2013. Ethno-ornithology and Conservation of wild birds in Semi-Arid Caatinga of Northeastern Brazil. Ethnobiol Med 9 (14): 1-12.

Alves RRN, Roasa LL, Neto NAL, Voeks R. 2012. Animals for the Gods: Magical and Religious Faunal Use and Trade in Brazil. Hum Ecol 40: 751-780.

Arief H, Mujiarto J, Rahman A. 2017. Diversity and Wildlife Conservation Status in Pt. Riau Sawitindo Abadi. Media Konservasi 20 (1): 159-165. [Indonesian]

Beastall C, Shepherd CR, Hadiprakarsa, Y, Martyr D. 2016. Trade in the Helmeted Hornbill Rhinoplax vigil: the ivory hornbill. Bird Conserv Intl 26: 137-146.

Buckley FG. 1968. Behaviour of the Blue-Crowned Hanging Parrot Loriculus galgulus with comparative notes on the vernal Hanging Parrot L.vernalis. Intl J Avian Sci 110 (2): 145-164.

David, JP, Mankadan R, Ganesh T. 2015. Frugivory and seed dispersal by birds and mammals in the coastal tropical dry evergreen forests of southern India. Trop Ecol 56 (1): 41-55.

Diamond J. Bishop KD. 1999. Etnoornithology of the Ketengban People Indonesian New Guinea. In: Medin DL, Atran S (eds.). Folk Biology. Massachusetts Institute of Technology, London. 
Eaton JA, Shepherd CR, Rheindt FE, Harris JBC, van Balen SB, Wilcove DS, Collar NJ. 2015. Trade-driven extinctions and near-extinctions of avian taxa in Sundaic Indonesia. Forktail 31: 1-12.

Edorita W, Jayakusumua Z. 2018. Implementation of the values and customs of local wisdom in preserving the forests, rivers and lakes of the village of Buluh Cina Siak Hulu Kampar District. Riau Low Journal 2: 2. [Indonesian]

Ellen RF. 1993a. Nualu Ethnozoology a Systematic Inventory. CSACMonograph 6 South-East Asia Series, Canterbury, UK.

Ellen RF. 1993b. The cultural relations of classification: an analysis ofNualu animal categories from Central Ceram. Cambridge University Press, Cambridge.

Franco FM, Minggu MJ. 2019. When the seeds sprout, the hornbills hatch understanding the traditional ecological knowledge of the Ibans of Brunei Darussalam on Hornbills. J Ethnobiol Ethnomed 15: 46.

Gonzales JCT. 2011. Enumerating the ethnoornithological importance of Philippines Hornbills. Raffles Bull Zool 24: 149-161.

Iskandar J, Iskandar JS, Partasasmita R. 2016. The local knowledge of the rural people on species, role and hunting of birds: Case study in Karawanwangi Village, West Java, Indonesia. Biodiversitas 17 (2): 435-446.

Iskandar J. 2012. Ethnobiological and Sustainable Development. Research Center for Public Policy and Territorial, University of Padjadjaran, Sumedang. [Indonesian]

IUCN. 2018. Helmeted Hornbill (Rhinoplax vigil): Status Review, RangeWide Conservation Strategy and Action Plan (2018-2027). IUCN SSC Hornbill Specialist Group, Sarawak.

King B, Dickinson EC, Woodcock. 1975. A Field Guide to the Birds of Southeast Asia. Collins, London.

Lestari S, Riyanti MT. 2017. Kajian Motif Tenun Songket Melayu Siak Tradisional Khas Riau. Dimensi DKV. 2(1). [Indonesian]

Mackinnon J, Phillipps K, Balen BV. 1992. The birds in Sumatra, Java, Bali and Borneo. Center for Biology-LIPI. Bogor. [Indonesian]

Mahawar MM, Jaroli DP.2008. Traditional Zootherapeutic studies in India: a review. J Ethnobiol Ethnomed 4: 17. DOI: 10.1186/17464269-4-17.

Mudappa D, Raman TRS. 2009. A Conservation Status Survey of Hornbills (Bucerotidae) in the Western Ghats, India. Indian Birds 5 (4): 90-102.
Naniwadekar R, Datta A. 2013. Spatial and temporal variation in hornbill densities in Namdapha Tiger Reserve, Arunachal Pradesh, Nort-east India. Trop Conserv Sci 6 (6): 734-748.

Newing H, Eagle CM, Puri RK, et al. 2011. Conducting research in Conservation: Social Science Methods and Practice. Routledge, London.

Rozzi, R. 2010. Multi-Ethnic Bird Guide of the Subantarctic Forest of South America. University of North Texas Press, Denton.

Sabaruddin, Yoza D, Oktorini Y. 2017. Diversity of Bird Species in The Forest Reserve of Kenegerian Rumbio Kampar Subdistricts Kampar Districts Riau Province. Jom Faperta Ur 4(2): 1-12. [Indonesian]

Semiawan C. 2004. The challenge of a multicultural education in a pluralistic society; the Indonesian case. In: Sunarto K, Heng RHK, Saifuddin AF (eds.). Multicultural education in Indonesia and South East Asia, Jurnal Antropologi Indonesia, Depok.

Silviyanti N, Nurdjali B, Kartikawati SM. 2016. Ethno-ornithology study of birds as a form of local wisdom of communities in Pematang Gadung Village, Ketapang District. J Sustain For 4 (2): 176-184. [Indonesian]

Sodhi NS, Sekercioglu CH, Barlow J, Robinson SK. 2011. The State of Tropical Bird Biodiversity. In: Sodhi NS, Sekercioglu CH, Barlow J, Robinson SK Conservation of Tropical Birds. 1st ed. Blackwell, West Sussex, UK.

Sukmantoro W, Irham M, Novarino W, Hasudungan F, Kemp N, Muchtar M. 2007. Indonesian Bird Checklist (IBC) No. 2. Indonesian Ornithologist' Union, Bogor. [Indonesian]

Syaputra A, Gunawan H, Yoza D. 2017. Composition and Diversity of Birds in Several Types of Green Open Spaces in Rengat City, Indragiri Hulu District. J Riau Biol 2(1): 1-7. [Indonesian]

Titisari PW, Syamsudin TS, Sjarmidi A. 2016. The utilization of bioresources by local communities at Giam Siak Kecil-Bukit Batu Biosphere Reserve, Riau Province, Indonesia. Biodiversitas 17 (2): 872-886.

Trisurat Y, Chimchome V, Pattanavibool A, Jinamoy S, Thongaree S, Kanchanasakha, Simcharoen S, Sribuarod K, Mahannop N, and Poonswad P. 2013. An assessment of the distribution and conservation status of hornbill species in Thailand. Fauna Flora Int 110

Van NDN, Tap N. 2008. An Overview of the Use of Plants and Animals in Traditional Medicine Systems in Vietnam. TRAFFIC Southeast Asia, Hanoi. 